Penelitian

\title{
Folikel Pre-Ovulatori Sapi PO Dara yang Distimulasi Menggunakan PMSG Dosis Rendah
}

\section{Pre-ovulatory Follicle of Crossed Ongole Heifer Stimulated by Using Low Dose of PMSG}

\author{
Krido Brahmo Putro', Amrozi ${ }^{2}$, Adi Winarto ${ }^{3}$, Arief Boediono ${ }^{3}$, Wasmen Manalu ${ }^{3}$ \\ ${ }^{1}$ Program Studi IImu-IImu Faal dan Khasiat Obat, Departemen Anatomi, Fisiologi, dan Farmakologi, FKH IPB \\ ${ }^{2}$ Departemen Klinik, Reproduksi, dan Patologi FKH IPB \\ ${ }^{3}$ Departemen Anatomi, Fisiologi, dan Farmakologi FKH IPB \\ *Penulis untuk korespondensi: amrozi217@gmail.com \\ Diterima 15 Januari 2020, Disetujui 17 Juliz 2020
}

\begin{abstract}
ABSTRAK
Penelitian ini bertujuan untuk mengetahui perkembanganfolikel sapi PO dara yang distimulasi menggunakan PMSG dosis rendah (dosis non-superovulasi) dan perolehan folikel dominan pre-ovulatori sebagai informasi dasar untuk penerapan intrauterine programming pada sapi. Sapi PO dara berjumlah sembilan ekor dibagi ke dalam tiga kelompok dosis PMSG, yaitu kontrol ( $\mathrm{NaCl} 0.9 \%$ sebagai placebo), dosis PMSG 0.5, dan 1.0 IU/kg BB. Injeksi PMSG dilakukan pada awal gelombang folikel ke-2 berdasarkan perubahan dinamika ovari yang dikonfirmasi menggunakan USG diikuti injeksi $\mathrm{PGF}_{2 a} 48$ jam kemudian. Perkembangan folikel sejak injeksi PMSG hingga terbentuknya pre-ovulatori folikel (POF) diamati dan dipetakan menggunakan USG. Jumlah POF tertinggi terdapat pada dosis PMSG $1.0 \mathrm{IU} / \mathrm{kg}$ BB $(4.67 \pm 1.67)$ secara signifikan $(P<0.05)$, sedangkan POF yang terbentuk pada dosis PMSG $0.5 \mathrm{IU} / \mathrm{kg}$ BB berjumlah satu, sama dengan kelompok kontrol $(P>0.05)$. Meskipun jumlah POF yang terbentuk berjumlah satu, namun rataan diameter dan volume kelompok sapi dosis $0.5 \mathrm{IU} / \mathrm{kg}$ B B lebih besar $16.13 \%$ dan $57.14 \%$ secara berurutan dibandingkan kelompok kontrol, diikuti oleh dosis $1.0 \mathrm{IU} / \mathrm{kg}$ BB dengan nilai tertinggi secara signifikan $(\mathrm{P}<0.05)$. Berdasarkan hasil tersebut dapat diketahui bahwa PMSG $0.5 \mathrm{IU} / \mathrm{kg}$ BB dapat terkontrol sehingga dapat digunakan sebagai metode pendekatan intrauterine programming pada hewan monotokus.
\end{abstract}

Kata kunci: sapi PO, intrauterine programming, folikel pre-ovulatori, PMSG

\begin{abstract}
This research was aimed to study the follicle development of crossed ongole heifer stimulated by using low dose of PMSG as a basic study to implement the intrauterine programming for bovine. Three groups of heifers ( $n=3$ per group) were divided for three different doses of PMSG (in IU/kg BB), i.e., control (0), 0.5 , and 1.0 respectively. The PMSG injection were done at early stage of second follicular waves confirmed by using USG and followed by PGF 2 injection 48 hours later. Follicle development was tracked by using USC daily since the injection of PMSG until formation of dominant pre-ovulatory follicle(POF). The highest obtained POF were found at heifers injected with PMSG at a dose 1.0 $\mathrm{IU} / \mathrm{kg}$ BW $(4.67 \pm 1.67)(P<0.05)$. However, heifers of second group (dose of PMSG at $0.5 \mathrm{IU} / \mathrm{kg} \mathrm{BW}$ ) only have one POF and there was no significant different compared to control group ( $P>0.05)$. Eventhough the obtained POF of second group only one follicle, the mean of diameter and volume were higher $16.13 \%$ and $57.14 \%$ respectively, compared to control group, followed by the highest dose significantly $(P<0.05)$. Based on the results, the PMSG at the dose of 0.5 $\mathrm{IU} / \mathrm{kg}$ BW could be used as a method to implement intrauterine programming in monotocus animal, especially bovine.

Keywords: crossed-ongole heifer, intrauterine programming, pre-ovulatosy follicle, PMSC
\end{abstract}




\section{PENDAHULUAN}

Reproduksi pada ternak menjadi salah satu faktor utama dalam mengoptimalkan produksi ternak. Berbagai metode telah dikembangkanuntuk meningkatkan kualitasproduksi ternak, di antaranya intrauterine programming yang telah digulirkan sejak dua dekade terakhir. Intrauterine programming merupakan suatu konsep pendekatan peningkatan reproduksi dan produksi melalui perbaikan kondisi lingkungan intrauterus selama masa kebuntingan (Fowden \& Forehead, 2004). Pendekatan ini terbukti dapat menyediakan lingkungan uterus yang lebih baik di masa kebuntingan dan meningkatkan potensi kelahiran anakan dengan kualitas yang lebih baik dari berbagai aspek.

Penerapan intrauterine programming melalui pendekatan superovulasi menggunakan Pregnant Mare Serum Gonadotrophin (PMSG) sebelum kawin telah diterapkan secara luas pada ternak kecil. Metode ini telah terbukti dapat meningkatkan performans produksi pada domba(Manalu et al., 1998; Frimawaty \& Manalu, 1999; Adriani et al., 2007; Andriyanto \& Manalu, 2012), kambing(Andriyanto \& Manalu, 2011), dan babi (Mege et al., 2007).

Metode ini menjadi tantangan tersendiri apabila diterapkan pada hewan monotokus, terutama sapi sebagai ruminansia besar utama penghasil susu dan daging. Penggunaan PMSG pada sapi umumnya digunakan untuk kepentingan produksi embrio sehingga akan mengganggu fisiologi kebuntingan sapi (sebagai hewan monotokus) apabila diterapkan dengan dosisnomal untuk kepentingan intrauterine programming. Superovulasi menggunakan preparat gonadotrophin yang diikuti perkawinan memiliki kecenderungan menyebabkan multiple calving yang dapat menjadimasalah pada sapi di trimester kedua hingga ketiga masa kebuntingan. Selain tantangan tersebut, sebagian besar penelitian masih terkonsentrasi pada hasil akhir penerapan intrauterine programming sehingga informasi dasar mengenai pengaruh PMSG pada perkembangan folikel dalam rangkamenjalankan intrauterine programming masih terbatas. Penelitian ini bertujuan untuk mempelajari perkembangan folikel sapi PO dara sejak diinjeksi menggunakan PMSG dosis rendah (non-superovulasi) hingga fase siap kawin (estrus).

\section{BAHAN DAN METODE}

\section{Rancangan Penelitian}

Objek penelitian ini adalah sapi PO dara yang berumur antara 18-24 bulan dengan kondisi fisik sehat, BCS antara 2.5-3, dan telah diseleksi kesehatan reproduksinya menggunakan realtime utrasonograph (USG). Kesehatan siklus reproduksinya ditentukan berdasarkan konfirmasi keberadaan ukuranfolikel yang bervariasi dan/atau keberadaan corpus luteum $(\mathrm{CL})$ yang menandakan terdapat dinamika folikel (siklik), sedangkan saluran reproduksinya dipastikan bersih, bebas eksu dat, dan tidak terdapat kelainan yang lainnya.

Sembilan ekor sapi PO dara yang telah terseleksi diaklimatisasi terlebih dahulu selama satu bulan dengan diberi multivitamin dan obat cacing untuk menunjang kesehatannya. Selama aklimatisasi, sapi dipelihara di dalam kandang individual dan diberi pakan konsentrat $\pm 3 \mathrm{~kg}$ per hari yang terbagi dalam dua kali pemberian, dan rumput/hijauan sebanyak \pm $30 \mathrm{~kg} /$ hari serta air minum ad libitum. Setelah aklimatisasi, sapi dibagi ke dalam tiga kelompok $(n=3)$, yaitu kelompok kontrol yang diinjeksi $\mathrm{NaCl} 0.9 \%$ sebagai pengganti PMSG, kelompok dosis PMSG 0.5 $\mathrm{IU} / \mathrm{kg} \mathrm{BB}$, dan kelompok dosis PMSG $1.0 \mathrm{lU} / \mathrm{kg}$ BB. Pemilihan dosis berdasarkan modifikasi dari penelitian Fu et al. (2013) yang memberikan perlakuan PMSC berbagai dosis pada sapi chinese holstein, dengan dosis terendah adalah $2.5 \mathrm{lU} / \mathrm{kg}$ BB. Dosis ini memiliki risiko multiple calving paling rendah.

Sebelum pemberian perlakuan, siklus estrus sapi disinkronisasi terlebih dahulu menggunakan $2 x$ penyuntikan hormon $\mathrm{PGF}_{2 a}$ dengan dosis $25 \mathrm{mg} / \mathrm{ekor}$ dengan interval 12 hari. Hari ke-o dihitung saat terjadi estrus yang muncul \pm 48 jam setelah penyuntikan $\mathrm{PGF}_{2 a}$. Pemberian PMSG dilakukan pada awal gelombang folikel kedua yang dikonfirmasi menggunakan USG atas kemunculan kelompok folikel kecil dan menurunnya diameter folikel dominan gelombang folikel pertama. Titik kritis program stimulasi ini adalah pada waktu pemberian PMSG.

Hormon PMSG diberikan pada saat dimulainya gonadotrophin dependent follicle development yang ditandai dengan kemunculan kelompok folikel sebanyak 5-20 folikel berukuran $\geq 5 \mathrm{~mm}$ (Adams et al., 2008; Forde et al., 2011). Kemunculan kelompok folikel tersebut umumnya terjadi pada harike-2 atau ke-3 gelombang folikel (Evans \& Fortune 1997). Selanjutnya, dilakukan penyuntikan $\mathrm{PGF}_{2 a} 48$ jam pascapemberian PMSG dengan dosis $25 \mathrm{mg} /$ ekor untuk meluruhkan $\mathrm{CL}$ dan melanjutkan perkembangan folikel hingga dominan folikel pre-ovulatori (POF).

Perkembangan folikel diamati sejak penyuntikan PMSG hingga terbentuknya POF menggunakan USG setiap hari oleh operator dan waktu yang sama. Recording data dilakukan terhadap jumlah dan diameter folikel kecil (Fs) saat injeksi PMSG, jumlah dan 
diameter folikel sedang (Fs) dan folikel besar POF. Persentase folikel kecil yang terseleksi menjadi folikel sedang, dan persentase folikel sedang yang terseleksi menjadi folikle dominan POF dihitung untuk mengetahui pola seleksi folikel pada dosis PMSC yang berbeda. Secara lebih detail, persentase folikel kecil yang terseleksi menjadi folikel sedang dihitung dengan membandingkanjumlah total folikel sedang $(\Sigma \mathrm{Fs})$ terhadap jumlah total folikel kecil ( $\Sigma \mathrm{Fk})$ pada saat injeksi PMSG dalam persen, dengan rumus \%Fk terseleksi $=(\Sigma \mathrm{Fs} / \Sigma \mathrm{Fk}) \times 100 \%$. Selanjutnya, persentase Fs yang terseleksi menjadi POF dihitung dengan membandingkan total jumlah POF ( $\Sigma$ POF) terhadap jumlah $\Sigma \mathrm{Fk}$, dengan rumus \%Fs terseleksi $=(\Sigma \mathrm{POF})$ $\left.\sum F s\right) \times 100 \%$.

Selain parameter tersebut, diukur pula rataan dan total volume POF. Volume POF diukur berdasarkan metode yang dikembangkan oleh Pulley et al. (2013) dan dipakai dalam penelitian Andriyanto et al. (2015), yaitu dengan rumus $V=4 / 3 \times r^{3} \times \pi$, dengan $r=$ radius, $(r=[W / 2+H / 2) / 2], W=$ diameter terbesar pada satu POF, $\mathrm{H}=$ diameter terkecil pada POF yang sama). Selain karakteristik folikel, dilakukan uji korelasi antara dosis PMSG dengan jumlah folikel sedang, jumlah folikel dominan POF, persentase folikel kecil yang terseleksi, persentase folikel sedang yang terseleksi, rataan diameter dan volume POF, dan total rataan dan total volume POF untuk mengetahui keeratan hubungan antarvariabel.

\section{Analisis data}

Data yang diperoleh dianalisis dengan analisis sidik ragam (ANOVA). Apabila berpengaruh nyata, maka dilakukan uji lanjut dengan uji Duncan. Analisis regresi linear sederhana dilakukan untuk mengetahui korelasi antarvariabel pengamatan.

\section{HASIL}

Hasil penelitian menunjukkan bahwa dosis PMSC yang tertinggi (1.0 IU/kg BB) mampu meningkatkan seleksi folikel kecil menjadi folikel sedang dan seleksi folikel sedang menjadi folikel dominan POF secara signifikan $(P<0.05)$. Hasil ini tampak pada jumlah folikel sedang yang muncul, dan jumlah folikel dominan POF yang terbentuk (Tabel 1). Jumlah folikel sedang yang muncul pada kelompok dosis 0.5 IU/kg BB tidak menunjukkan perbedaan yang signifikan $(\mathrm{P}>0.05)$ pada kelompok kontrol, demikian pula jumlah folikel dominan POF yang terbentuk. Trend yang sama juga terlihat dari persentase folikel terseleksi, baik dari folikel kecil yang terseleksi men- jadi folikel sedang, maupun folikel sedang yang terseleksi menjadi folikel dominan POF.

Rataan diameter POF memiliki ukuran berbeda di antara ketiga kelompok. Dosis PMSG $1.0 \mathrm{IU} / \mathrm{kg} \mathrm{BB}$ memiliki rataan diameter terbesar dan signifikan pada kelompok kontrol, akan tetapi tidak signifikan pada kelompok dosis PMSG $0.5 \mathrm{IU} / \mathrm{kg}$ BB. Demikian pula pada rataan volume POF, dosis PMSG 1.0 memiliki rataan volume terbesar secara signifikan dibandingkan kelompok kontrol, sedangkan kelompok dosis PMSG 0.5 memiliki rataan volume POF yang tidak berbeda nyata baik pada kelompok kontrol maupun kelompok dosis PMSG 1.o. Total diameter POF antara kelompok kontrol dan kelompok dosis PMSG 0.5 tidak terdapat perbedaan yang signifikan, akan tetapi kelompok dosis 1.0 memiliki total diameter terbesar secara signifikan dengan selisih nilai yang cukup jauh. Trend yang sama juga terjadi pada parameter total volume POF. Dosis PMSG 1.0 memiliki total volume POF terbesar secara signifikan, sedangkan dosis PMSG 0.5 dan kelompok kontrol memiliki nilai total volume POF jauh lebih rendah dan tidak terdapat perbedaan signifikan di antara dua kelompok tersebut. Hasil tersebut menunjukkan bahwa selisih nilai yang cukup jauh merupakan konsekuensi dari jumlah POF yang terbentuk. Dosis PMSG 1.0 memiliki jumlah POF $4.67 \pm 1.67$, sehingga berpengaruh pada nilai total diameter dan total volume POF. Gambaran USG memperlihatkan perbedaan yang signifikan di antara ketiga kelompok dosis dengan dosis tertinggi yang memiliki folikel dominan POF terbanyak (Gambar 1).

Selanjutnya, keeratan hubungan antara dosis PMSG dan jumlah folikel sedang, jumlah folikel dominan POF, persentase folikel terseleksi dari folikel kecil, persentase folikel terseleksi dari folikel sedang, rataan diameter POF, rataan volume POF, total diameter POF, dan total volume POF disajikan pada Tabel 2.

Analisis regresi yang disajikan pada Tabel 2 menunjukkan bahwa PMSG dosis rendah memiliki korelasi positif dan signifikan dengan jumlah folikel dominan POF, persentase folikel kecil yang terseleksi menjadi folikel sedang, persentase folikel sedang yang terseleksi menjadi folikel dominan POF, rataan diameter POF, rataan volume POF, total diameter POF, dan diameter POF dengan nilai koefisien korelasi sebesar $0.75,0.71,0.75,0.79,0.85$, 0.85 , dan 0.88 secara berurutan $(P<0.05)$. Akan tetapi pada awal proses dinamika ovari pascainjeksi PMSG, parameter jumlah folikel sedang yang terbentuk tidak terjadi korelasi yang signifikan $(P>0.05)$, meskipun nilai korelasinya masih di atas 
4 | Putro et al.

Tabel 1 Jumlah folikel kecil ( $\Sigma F k$ ) saat injeksi PMSG, jumlah folikel sedang ( $\Sigma F s)$, jumlah folikel dominan preovulatori ( $\Sigma \mathrm{POF}$ ), rataan diameter POF, rataan volume POF, total diameter POF, total volume POF pada sapi yang disuntik PMSG dengan dosis berbeda

\begin{tabular}{lccc}
\hline & \multicolumn{3}{c}{ Dosis PMSG (IU/kg BB) } \\
\cline { 2 - 4 }$\sum$ & Kontrol & 0.5 & 1.0 \\
\hline FF saat injeksi PMSG & $21.00 \pm 2.45$ & $17.33 \pm 2.87$ & $20.00 \pm 2.16$ \\
$\Sigma$ Fs & $3.67 \pm 0.67^{\mathrm{a}}$ & $4.00 \pm 0.58^{\mathrm{a}}$ & $8.33 \pm 2.33^{\mathrm{a}}$ \\
$\Sigma$ POF & $1 \pm 0^{\mathrm{a}}$ & $1 \pm 0^{\mathrm{a}}$ & $4.67 \pm 1.67^{\mathrm{b}}$ \\
Fk terseleksi (\%) & $17.26 \pm 1.91^{\mathrm{a}}$ & $24.09 \pm 4.91^{\mathrm{a}}$ & $41.49 \pm 10.47^{\mathrm{a}}$ \\
Fs terseleksi (\%) & $28.89 \pm 4.44^{\mathrm{a}}$ & $26.11 \pm 3.89^{\mathrm{a}}$ & $56.84 \pm 5.04^{\mathrm{b}}$ \\
Rataan diameter POF $(\mathrm{cm})$ & $1.24 \pm 0.15^{\mathrm{a}}$ & $1.44 \pm 0.78^{\mathrm{ab}}$ & $1.59 \pm 0.16^{\mathrm{b}}$ \\
Rataan volume POF $\left(\mathrm{cm}^{3}\right)$ & $0.84 \pm 0.31^{\mathrm{a}}$ & $1.32 \pm 0.16^{\mathrm{ab}}$ & $1.75 \pm 0.34^{\mathrm{b}}$ \\
Total diameter POF $\left(\mathrm{cm}^{\mathrm{b}}\right.$ & $1.24 \pm 0.15^{\mathrm{a}}$ & $1.44 \pm 0.78^{\mathrm{a}}$ & $5.56 \pm .37^{\mathrm{b}}$ \\
Total volume POF $\left(\mathrm{cm}^{3}\right)$ & $0.84 \pm 0.31^{\mathrm{a}}$ & $1.32 \pm 0.16^{\mathrm{a}}$ & $7.89 \pm 2.96^{\mathrm{b}}$ \\
\hline
\end{tabular}

Huruf superscript berbeda pada baris yang sama menunjukkan nilai berbeda nyata $(p<0.05)$

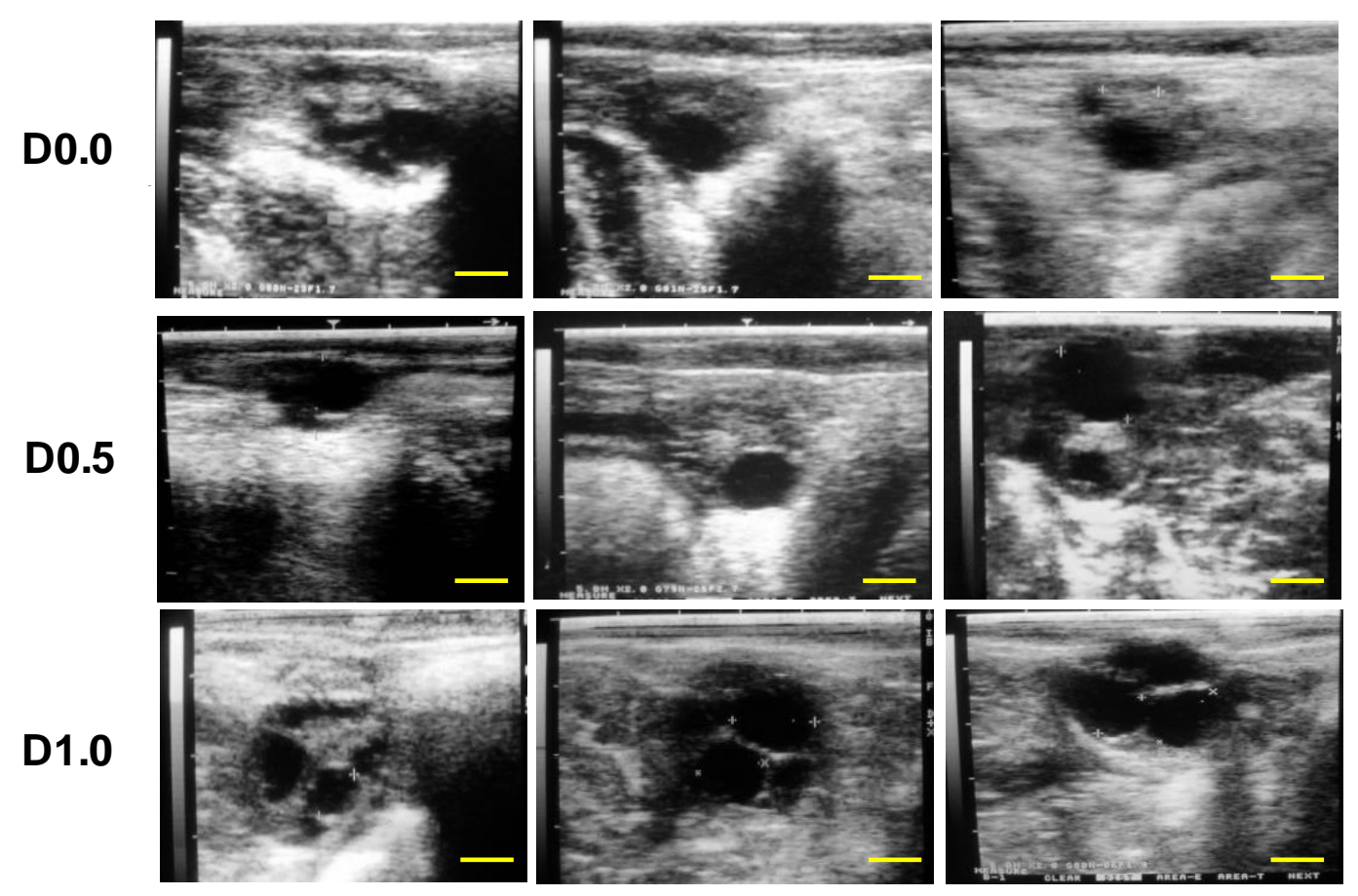

Gambar 1 Citra USG folikel dominan POF pada sapi yang diinjeksi PMSG dengan dosis berbeda. Do.0 = kontrol, Do.5 = dosis PMSG 0.5 IU $/ \mathrm{kg} \mathrm{BB,} \mathrm{D1.0} \mathrm{=} \mathrm{dosis} \mathrm{PMSG} 1.0 \mathrm{IU} / \mathrm{kg} \mathrm{BB}, \mathrm{bar}=1 \mathrm{~cm}$

0.5 (0.65). Secara garis besar, hasil observasi tersebut menunjukkan bahwa dosis PMSG yang rendah dapat mengontrol formasi folikel dominan POF yang pada akhirnya memberikan peluang besar penerapan intrauterine programming khususnya pada sapi, dan hewan monotokus lainnya secara umum.

\section{PEMBAHASAN}

Penelitian ini dibatasi pada observasi perkembangan folikel dan perolehan folikel dominan POF pada sapi PO dara yang distimulasi menggunakan
PMSG dosis rendah (nonsuperovulatori). Hasil penelitian secara umum menunjukkan bahwa PMSG dengan dosis nonsuperovulatori yang diinjeksi pada awal gelombang folikel ke-2 dan diikuti injeksi PGF $_{2 a}$ 48 jam kemudian mampu meningkatkan seleksi folikel kecil menjadi folikel sedang, dan folikel sedang menjadi folikel dominan POF. Meskipun terdapat peningkatan aktivitas seleksi folikel, kelompok dosis PMSG $0.5 \mathrm{lU} / \mathrm{kg}$ BB tidak meninjukkan peningkatan formasi folikel dominan POF yakni sama dengan kelompok kontrol. Dosis PMSG yang lebih tinggi (1.0 IU/kg BB) terbukti mampu meningkatkan seleksi 
Tabel 2 Hasil analisis regresi linear hubungan antara dosis PMSG dengan jumlah folikel sedang, jumlah folikel dominan POF, persentase folikel terseleksi dari folikel kecil, persentase folikel terseleksi dari folikel sedang, rataan diameter POF, rataan volume POF, total dia meter POF, dan total volume POF

\begin{tabular}{llllll}
\hline Parameter X & \multicolumn{1}{c}{ Parameter $\mathrm{Y}$} & Persamaan & $\mathrm{R}$ & $\mathrm{R}^{2}$ & $\mathrm{P}$ \\
\hline & Jumlah folikel sedang & $\mathrm{Y}=4.67 \mathrm{x}+3$ & 0.65 & 0.42 & 0.060 \\
& Jumlah folikel dominan POF & $\mathrm{Y}=3.67 \mathrm{x}+0.39$ & 0.75 & 0.57 & 0.020 \\
& \% folikel kecil yang terseleksi & $\mathrm{Y}=24.23 \mathrm{x}+15.49$ & 0.71 & 0.50 & 0.033 \\
\multirow{5}{*}{ Dosis PMSG } & \% folikel sedang yang terseleksi & $\mathrm{Y}=27.95 \mathrm{x}+23.30$ & 0.75 & 0.56 & 0.020 \\
& Rataan diameter POF & $\mathrm{Y}=0.34 \mathrm{x}+1.25$ & 0.79 & 0.62 & 0.011 \\
& Rataan volume POF & $\mathrm{Y}=0.90 \mathrm{x}+0.85$ & 0.85 & 0.72 & 0.004 \\
& Total diameter POF & $\mathrm{Y}=6.06 \mathrm{x}+0.30$ & 0.85 & 0.73 & 0.007 \\
& Total volume POF & $\mathrm{Y}=7.04 \mathrm{x}-0.17$ & 0.88 & 0.67 & 0.004 \\
\hline
\end{tabular}

folikel pascainjeksi PMSG sekaligus meningkatkan formasi folikel dominan POF hingga berjumlah 4.67 \pm 1.67 folikel. Akan tetapi, dosis PMSG 1.0 memberikan peluang yang besar akan terjadinya multiple calving apabila kemudian sapi dikawinkan.

Seleksi folikel merupakan mekanisme kompleks yang melibatkan dua faktor utama, yaitu signal ekstraovari seperti hormon gonadotrophin dan hormon metabolik, dan faktor intraovari (Webb et al., 1999). Dalam perkembangannya, folikel memiliki dua fase, yaitu fase gonadotrophin-dependent dan fase gonadotrophin-independent (Webbet al., 2004). Pertumbuhan folikel pada awal gelombang folikel terjadi akibat gonadotrophin-dependent yang dicirikan dengan peningkatan konsentrasi FSH yang bersirkulasi dan peningkatan sebaran reseptor FSH (FSHr) pada sel granulosa folikel (Evand \& Fortune 1997; Adams et al., 2008; Forde et al., 2011). Selanjutnya, pertumbuhan folikel terpicu dengan ikatan FSH-FSHr (FSH binding) yang menginisiasi pertumbuhan seluler dan proliferasi (Richards at al., 1998; Webb et al., 1999; Findlay \& Drummond 1999; Saraiva et al., 2011).

Injeksi PMSG pada sapi dengan dosis superovulatori saat terjadi gonadotrophin-dependent terbukti meningkatkan jumlah folikel yang direkrut dan jumlah folikel terseleksi menjadi dominan folikel (Mapletoft et al., 2002). Peningkatan jumlah folikel direkrut dan terseleksi merupakan akibat pengaruh PMSG yang mampu meningkatkan kejadian FSHbinding. LaPolt et al. (1992) melaporkan bahwa 24 jam setelah pemberian PMSG terjadi perkembangan folikel yang dibuktikan dengan peningkatan mRNA reseptor FSH pada tikus yang terus beratambah hingga 52 jam, sejalan dengan meningkatnya FSHbinding. Hasil penelitian kami menunjukkan terjadi peningkatan jumlah folikel kecil yang terseleksi menjadi folikel sedang dengan peningkatan sebesar $39.57 \%$ dan $140.38 \%$ pada PMSG dosis 0.5 dan 1.0 $\mathrm{IU} / \mathrm{kg}$ BB secara berurutan. Hasil analisis regresijuga menunjukkan hubungan yang kuat antara peningkatan dosis PMSG dengan kenaikan persentase seleksi folikel kecil dengan nilai koefisien $r$ 0.71 dan signifikan $(\mathrm{P}<0.05)$. Temuan ini menunjukkan indikasi kuat bahwa terjadi peningkatan pertumbuhan seluler dan proliferasi sel granulosa pada folikel kecil yang diduga kuat akibat peningkatan sebaran FSHr dan FSH-binding oleh PMSG, sekalipun inisiasi PMSG menggunakan dosis rendah (nonsuperovulatori).

Folikel kecil yang terseleksi menjadi folikel sedang akan terus berkembang menunju folikel dominan melalui deviasi. Regulasi hormon FSH yang awalnya men-trigger perkembangan folikel, akan terhenti dengan segera setelah terjadi deviasi yang ditandai terseleksinya folikel sedang yang terus tumbuh menjadi folikel dominan dan berhentinya pertumbuhan folikel lainnya (Adams et al., 1993; Ginther et al., 1996). Hal ini akibat feedback negatif oleh inhibin dan intrafollicular growth factor (IGF) yang meningkat seiring berkembangnya folikel (Beg et al., 2001). Peran FSH yang digantikan oleh LH diduga oleh meningkatnya ekspresi reseptor LH ( $\mathrm{LHr}$ ) yang mulai meningkat sejak awal terjadinya deviasi (Wohlres-Viana et al., 2017). Secara lebih detail, Martinez et al. (2018) dalam penelitiannya baru-baru ini menjelaskan bahwa terjadinya divergensi folikel ini bersamaan dengan peningkatan sekresi LH yang menyebabkan stimulasi reseptor $\mathrm{LH}(\mathrm{LHr})$ pada sel theca folikel dominan dan melalui kaskade second messenger, produksi androgen meningkatkan stimulasi IGF.

Terseleksinya folikel dominan disebabkan oleh kemampuan folikel bertahan dalamkondisi rendah 
FSH. Findlay et al. (2019) menjelaskan kemampuan bertahan ini disebabkan oleh peran aksi parakrin growth factors, seperti vascular endothelial growth factor, insulin-like growth factor 1 (IGF 1), dan estrogen. Selain itu, oosit ternyata memiliki peran penting dalam proses seleksi folikel dengan meningkatkan pertumbuhan folikel awal (early follicle growth) dan mengontrol pertumbuhan secara otonom melalui produksi dan aksi parakrin growth differentiation factor 9 (GDF 9), bone morphogenetic protein 15 (BMP 15), dan cumulin. Injeksi PMSG pada penelitian ini terbukti mampu meningkatkan seleksi folikel sedang menjadi folikel dominan POF pada dosis tertinggi (1.0 IU/kg BB), meskipun tidak membawa perubahan signifikan pada dosis yang lebih rendah ( $0.5 \mathrm{IU} / \mathrm{kg} \mathrm{BB})$. Berdasarkan penelitian terbaru yang berkaitan dengan kemampuan bertahan folikel dominan yang dijelaskan oleh Wohlres-Viana et al. (2017), Martinez et al. (2018), dan Findlay et al. (2019), terdapat indikasi kuat bahwa terjadi peningkatan sekresi dan aktivitas parakrin growth factor dan pengaruh oosit meskipun PMSG diberikan pada dosis nonsuperovulatori.

Injeksi PMSG yang diduga meningkatkan aktivitas sintase dan sekresi faktor pertumbuhan folikel ini terindikasi memiliki hubungan dengan meningkatnya diameter dan volume folikel dominan POF. Rataan diameter dan volume folikel dominan POF meningkat seiring dengan dosis PMSG yang lebih tinggi. Dosis PMSG tertinggi memiliki rataan diameter dan volume POF paling tinggi dan signifikan dibandingkan dengan kelompok kontrol $(P<0.05)$. Dosis PMSG $0.5 \mathrm{IU} / \mathrm{kg}$ BB memiliki nilai rataan diameter dan volume yang tidak signifikan terhadap kelompok kontrol dan kelompok dosis $1.0 \mathrm{lU} / \mathrm{kg}$ BB $(P>0.05)$. Meskipun tidak terdapat perbedaan yang signifikan, terdapat kenaikan diameter dan volume sebesar $16.13 \%$ dan $57.14 \%$ secara berurutan. Hasil ini menunjukkan bahwa terdapat peningkatan volume folikel dominan POF pada sapi yang diinjeksi PMSC dosis nonsuperovulatori yang didukung hubungan yang kuat dan dibuktikan dengan hasil analisis regresi antara dosis PMSG dengan parameter rataan diameter POF, rataan volume POF, total diameter POF, dan total volume POF dengan nilai koefisien $r$ masing-masing $0.79,0.85,0.85$, dan $0.88(P<0.05)$.

Dosis PMSG nonsuperovulatori berpeluang besar untuk diterapkan sebagai metode intrauterine programming pada hewan monotokus. Penelitian ini memberikan informasi yang jelas bahwa PMSG dosis nonsuperovulatori mampu menurunkan jumlah folikel dominan POF yang terbentuk sehingga menurunkan risiko multiple calving apabila diterapkan pada hewan monotokus, khususnya sapi.
Berdasarkan hasil penelitian, dapat dikemukakan bahwa dosis PMSG $0.5 \mathrm{IU} / \mathrm{kg}$ BB memiliki peluang besar untuk dapat diterapkan pada hewan monotokus, sedangkan dosis $1.0 \mathrm{IU} / \mathrm{kg}$ BB masih memberikan peluang multiple calving akibat jumlah folikel dominan POF yang terbentuk masih tinggi.

\section{UCAPAN TERIMA KASIH}

Penelitian ini didanai oleh Kementrian Riset, Teknologi, dan Pendidikan Tinggi (Kemenristek Dikti) Republik Indonesia dengan skema beasiswa PMDSU tahun 2016.

"Penulis menyatakan tidak ada konflik kepentingan dengan pihak-pihak yang terkait dalam penelitian ini".

\section{DAFTAR PUSTAKA}

Adams GP, Kot K, Smith CA, Ginther OJ. 1993. Selection of a dominant follicle and suppression of follicular growth in heifers. Animal Reproduction Science 30: 259-271.

Adams GP, Jaiswal R, Singh J, Malhi P. 2008. Progress in understanding ovarian follicular dynamic in cattle. Theriogeology 69 (1): 72-80.

Adriani, Sudono A, Sutardi T, Manalu W, Sutama IK, 2007. Prenatal growth in uterus of does by superovulation. HAYATI Journal of Bioscience 14: 44-48.

Andriyanto, Amrozi, Rahminiwati M, Boediono A, Manalu W. 2015. Korelasi folikel dominan akibat penyuntikan hormon pregnant mare serum gonadotrophin dengan peningkatan respon berahi pada kambing kacang. Jurnal Kedokteran Hewan 9(1): 20-23.

Andriyanto, Manalu W. 2011. Increased goat productivity through the improvement of endogenous secretion of pregnant hormones by using follicle stimulating hormone. Animal Production 9: 89-93.

Andriyanto, Manalu W. 2012. Improvement of small holder farms sheep productivity through the application of pregnant mare serum gonadotrophin. Jurnal Veteriner 13(3): 235-241.

Beg MA, BergfeltDR, Kot K, Wiltbank MC, Ginther OJ. 2001. Follicular-Fluid Factors and Granulosa-Cell Gene Expression Associated with Follicle Deviation in Cattle. Biology of Reproduction 64: 432-441.

Evans ACO, Fortune JE. 1997. Selection of the dominant follicle in cattle occurs in the absence of differences in the expression of messenger ribonucleic acid for gonadotropin receptors. Endocrinology 138: 2963-2971. 
Findlay JK, Drummond AE. 1999. Regulation of the $\mathrm{FSH}$ receptor in the ovary. Trends in Endocrinology and Metabolism 10(5): 183-188.

Findlay JK, Dunning KR, Gilchrist RB, HuttDarryl KJ, Russell L, Walters KA. 2019. Follicle Selection in Mammalian Ovary. In: Peter CKL, Eli YA (eds). The Ovary. $3^{\text {rd }}$ ed. Academic Press. Massachusetts. p3-21.

Frimawaty E, Manalu W. 1999. Milk yield and lactose synthetase activity in the mammary glands of superovulated ewes. Small Ruminant Research 33(3): 271-278.

Forde N, Beltman ME, Lonergan P, Diskin M, Roche JF, Crowe MA. 2011. Oestrous cy cles in Bos taurus cattle. Animal Reproduction Science 124: 163-169.

Fowden AL, Forhead AJ. 2004. Endocrine mechanism of intrauterine programming. Reproduction 127: 515-526.

Fu SB, Zhang HL, Riaz H, Ahmad S. 2013. Effects of Different Doses of PMSG on Reproductive Performance in Chinese Holstein Dairy Cows. Pakistan Veterinary Journal 33(2): 209-212.

Ginther OJ, Wiltbank MC, Fricke PM, Gibbons JR, Kot K. 1996. Selection of the Dominant Follicle in Cattle. Biology of Reproduction 55: 1187-1194.

LaPolt PS, Tilly JL, Aihara T, Nishimori K, Hsueh AJ. 1992. Gonadotropin-induced up- and down-regulation of ovarian follicle-stimulating hormone $(\mathrm{FSH})$ receptor gene expression in immature rats: effects of pregnant mare's serum gonadotropin, human chorionic gonadotropin, and recombinant FSH. Endocrinology 130(3): 1289 - 1295.

Manalu W, Sumaryadi MY, Sudjatmogo, Satyaningtijas AS. 1998. Effect of superovulation on maternal serum progesterone concentration, uterine and fetal weights at weeks 7 and 15 of pregnancy in Javanese Thin-Tail ewes. Small Ruminant Research 30: 171-176.

Mapletoft RJ, Steward KB, Adams GP. 2002. Recent advances in superovulation in cattle. Reproduction Nutrition Development 42: 601-611.
Martinez IYH, Santos APC, Bottino MP, Orlandi RE, Santos G, Simoes LMS, Souza JC, Diaza AMG, Binelli M, Sales JNS. 2018. Molecular and endocrine factors involved in future dominant follicle dynamics during the induction of luteolysis in Bos indicus cows. Theriogenology 111: 78-83.

Mege RA, Nasution SH, Kusumorini N, Manalu W. 2007. Growth and development of the uterus and placenta of superovulated gilts. HAYATI Journal of Bioscience 14: 1-6.

Pulley SL, Wallace LDJr, Mellison HL, Stevenson JS. 2013. Ovarian characteristics, serum concentration of progesterone and estradiol, and fertility in lactating dairy cows in response to equine chorionic gonadotropine. Theriogenology 79: 127-134.

Richards JS, Russell DL, Robker RL, Dajee M, Alliston

TN. 1998. Molecular mechanisms of ovulation and luteinization. Molecular and Celluller Endocrinology 145: 47-54.

Saraiva MV, Celestino JJ, Araújo VR, Chaves RN, Almeida AP, Lima-Verde IB, Duarte AB, Silva $G M$, Martins FS, Bruno JB. 2011. Expression of folliclestimulating hormone receptor (FSHR) in goat ovarian follicles and the impact of sequential culture medium on in vitro development of caprine preantral follicles. Zygote 19: 205-214.

Wohlres-Viana S, Arashiro EKN, Machado MA, Camargo LSA, Siqueira LGB, Palhao MP, Viana JHM. 2017. Intrafollicular oestradiol production, expression of the LH receptor (LHR) gene and its isoforms, and early follicular deviation in Bos indicus. Reproduction, Fertility and Development 29(10): 1958-1970.

Webb R, Campbell BK, Garverick HA, Gong JG, Guttierez CG, Armstrong DG. 1999. Molecular mechanism regulating follicular recruitment and selection. Journal of Reproduction and Fertility Supplement 54: 33-48.

Webb R, Garnsworthy PC, Gong JG, Armstrong DG. 2004. Control of follicular growth: local interactions and nutritional influences. Journal of Animal Science. 82: 63-74. 